\title{
Metastatic Oral Cavity Squamous Cell Carcinoma
}

National Cancer Institute

\section{Source}

National Cancer Institute. Metastatic Oral Cavity Squamous Cell Carcinoma. NCI

Thesaurus. Code C150206.

A squamous cell carcinoma of the oral cavity which has spread from the original site of growth to another anatomic site. 